\title{
Effects of ultraviolet radiation on aquatic bryophytes
}

\author{
Javier Martínez-Abaigar*, Encarnación Núñez-Olivera, María Arróniz-Crespo, \\ Rafael Tomás, Nathalie Beaucourt, Saúl Otero
}

\author{
Universidad de La Rioja. Complejo Científico-Tecnológico, Madre de Dios 51, 26006 Logroño (La Rioja), Spain \\ *Corresponding author: javier.martinez@daa.unirioja.es
}

\begin{abstract}
The depletion of the stratospheric ozone layer as a result of anthropogenic activities increases the ultraviolet-B (UV-B) irradiance at ground level. This may lead to harmful biological consequences affecting photosynthetic organisms. Mountain streams are especially exposed to a UV-B increase, and bryophytes play a key ecological role in them. In this paper, the effects of enhanced UV-B radiation on photosynthetic organisms in general and on bryophytes in particular are described. Hereafter, some results obtained by our group on the effects of UV-B on bryophytes from mountain streams are presented. Laboratory and field experiments show that these effects depend on the species, the environmental factors (such as temperature), and the origin of the samples (sun or shade conditions, low or high altitude). Among the variables measured, the maximum quantum yield of photosystem II $\left(\mathrm{F}_{\mathrm{v}} / \mathrm{F}_{\mathrm{m}}\right)$ and the level of UV-absorbing compounds seem to be the most responsive to enhanced UV-B, but no variable responded in the same manner in every species. The potential use of aquatic bryophytes as bio-indicators of changes in ambient UV-B radiation would require an adequate selection of both variables and species. Promising variables are $\mathrm{F}_{\mathrm{v}} / \mathrm{F}_{\mathrm{m}}$, the concentration of UV-absorbing compounds (especially if they are analyzed individually) and DNA damage, whereas the liverwort Jungermannia exsertifolia subsp. cordifolia has been revealed to be a good bio-indicator species. Globally, the responses of aquatic bryophytes to UV-B radiation and their protecting systems are still poorly characterized, and thus further study is required under both controlled and field conditions.
\end{abstract}

Keywords: aquatic bryophytes, mosses, liverworts, ultraviolet-B (UV-B) radiation, mountain streams, bio-indicators.

\section{RESUMEN}

La degradación antropogénica de la capa de ozono estratosférico provoca un aumento de la radiación ultravioleta-B (UV-B) en la superficie de La Tierra. Esto puede causar consecuencias biológicas nocivas en los organismos fotosintéticos. Los arroyos de montaña están especialmente expuestos al aumento de UV-B, y los briófitos desempeñan un papel ecológico crucial en estos ecosistemas. En el presente artículo, se describen los efectos de un aumento de radiación UV-B sobre los organismos fotosintéticos en general y sobre los briófitos en particular. A continuación, se presentan algunos resultados obtenidos por nuestro grupo de investigación sobre los efectos de la radiación UV-B en briófitos de arroyos de montaña. Los experimentos realizados tanto en campo como en laboratorio muestran que dichos efectos dependen de la especie considerada, de los factores ambientales (como la temperatura) y de la procedencia de las muestras (aclimatadas a condiciones de sol o sombra, provenientes de baja o elevada altitud). Entre las variables analizadas, el rendimiento cuántico máximo del fotosistema $I I\left(F_{v} / F_{m}\right)$ y el nivel de compuestos absorbentes de radiación UV parecen ser las que mejor responden a un aumento de UV-B, pero ninguna variable responde de la misma manera en todas las especies. El uso potencial de los briófitos acuáticos como bioindicadores de cambios en los niveles naturales de radiación UV-B requiere una selección adecuada tanto de las variables analizadas como de las especies empleadas. $F_{v} / F_{m}$ y la concentración de compuestos absorbentes de radiación UV (en especial si éstos son analizados individualmente), junto con los daños en el ADN, parecen ser las variables más prometedoras en este campo, mientras que la hepática Jungermannia exsertifolia subsp. cordifolia podría resultar una buena especie bioindicadora. Desde un punto de vista global, las respuestas de los briófitos acuáticos a la radiación UV-B, y los mecanismos protectores que utilizan para hacerle frente, están todavía poco caracterizados, y en consecuencia se necesita una mayor investigación en condiciones controladas y en campo.

Palabras clave: briófitos acuáticos, musgos, hepáticas, radiación ultravioleta-B (UV-B), arroyos de montaña, bioindicadores. 


\section{ULTRAVIOLET RADIATION AND ITS EFECTS ON PHOTOSYNTHETIC ORGANISMS}

Ultraviolet (UV) radiation induces many harmful effects in all living organisms, including humans. UV-C radiation $(<280 \mathrm{~nm})$ is ecologically not relevant since it is absorbed by atmospheric oxygen and ozone. However, both UV-B (280-315 nm) and UV-A (315-400 nm) penetrate to the biosphere and have significant biological effects, although only UV-B is absorbed by the stratospheric ozone layer. Biological responses to UV radiation are highly dependent on wavelength, and thus the biologically effective $\mathrm{UV}\left(\mathrm{UV}_{\mathrm{BE}}\right)$ can be calculated. $\mathrm{UV}_{\mathrm{BE}}$ encompass UV-A and UV-B, but, given the logarithmic increase of its effects with the decrease in wavelength, it is often dominated by UV-B, especially at its shorter wavelengths. Thus, most studies on the effects of UV radiation have dealt with UV-B.

UV-B irradiance at ground level depends on a number of factors, such as latitude, season, hour of the day, altitude, presence of clouds or aerosols, and surface reflectivity (Björn, 1999). In addition, ozone depletion as a result of anthropogenic emissions of halogenated carbon compounds leads to an increase in UV-B. In mid-latitudes, the ozone loss has led to a 6 to $12 \%$ increase in UV-B radiation above 1980 levels, and predicted changes show the ozone layer will remain vulnerable to further depletion in the near future (McKenzie et al., 2003). Consequently, studies on the effects of ambient and elevated UV-B irradiances are increasingly important. In humans, an excessive exposure to UV-B causes acute and chronic damage to eyes and skin, including sunburn and cancer, and compromises the immune system (Vanicek et al., 1999). In photosynthetic organisms, increased UV-B may cause diverse damage in the photosynthetic apparatus: pigment degradation, photoinhibition, and decreases in quantum yield, photosynthetic rate, and the activity of the Calvin cycle enzymes (Jansen et al., 1998). Also, DNA alterations, oxidative damage, and changes in mineral absorption can occur. This may lead to alterations in growth and development. However, some controversy about the ecological relevance of these effects still persists (Fiscus \& Booker, 1995; Allen et al., 1998; Searles et al., 2001a). At the ecosystem level, UV-B can affect decomposition, nutrient cycling, and trophic interactions (Caldwell et al., 1998). Photosynthetic organisms may develop a number of protection and repair mechanisms against the adverse effects of UV-B (Jansen et al., 1998): production of UV-absorbing compounds (flavonoids, phenyl-propanoids, mycosporine-like aminoacids, etc.), antioxidant and photo-protective mechanisms, and DNA-repairing processes.

Much of the research regarding the effects of UV-B on photosynthetic organisms has focused on terrestrial environments, especially using crop plants, whereas aquatic ecosystems have received less attention. The vast majority of the studies concerning aquatic ecosystems have dealt with marine phytoplankton and macroalgae (Figueroa \& Gómez, 2001; Day \& Neale, 2002; Häder et al., 2003; Helbling \& Zagarese, 2003), while the photosynthetic organisms from freshwater ecosystems have been less studied in line with their minor contribution to the global biomass and primary production of aquatic systems. However, rivers and lakes have an outstanding ecological importance as local systems and, because of their lower depth compared to marine systems, they are highly exposed to the harmful effects of UV-B radiation. In lakes, the penetration of UV radiation and its effects on phytoplankton have been the most studied topics (see for instance Villafañe et al., 1999; Huovinen \& Goldman, 2000; Laurion et al., 2000), but macrophytes have also been occasionally considered (Rae et al., 2001). In rivers, scarce work has been done (Rader \& Belish, 1997a, 1997b; Kelly et al., 2003), probably due to intrinsic methodological problems derived from their strongly dynamic environmental conditions (depth, discharge, water velocity, chemistry, etc.). 


\section{ULTRAVIOLET RADIATION AND BRYOPHYTES}

To our knowledge, around 65 papers have been published on the effects of UV-B radiation on bryophytes, among which only 49 contain original data (Table 1). Half of these are strictly bryological, whereas the remaining ones study bryophytes together with other photosynthetic organisms, such as vascular plants or lichens. The research on this topic has focused mainly on terrestrial and semi-aquatic bryophytes from Antarctic habitats and circumpolar heathlands and peatlands. The most used species belong to mosses: several Sphagnum species, Hylocomium splendens (typical from forest soils), and Polytrichum commune (typical from a wide range of acid habitats in damp to wet situations). Liverworts have been notably less studied than mosses, whereas no hornwort has been investigated.

Diverse methodological approaches have been applied. Studies have been conducted under both field and controlled conditions, and in the latter case both in the laboratory and in the greenhouse. The manipulation of UV-B has included the two main experimental options in the context of UV-B research (Rousseaux et al., 2004): exclusion experiments using filters, and supplementation using lamps to simulate ozone depletion. The duration of the experiments has been diverse, from a few hours of UV-B exposure (usually under controlled conditions) to several years (under field conditions). The bryophyte responses have been assessed using morphological and, especially, physiological variables: colour, symptoms of cell degradation, ultrastructural damage, sclerophylly, reproductive effort, growth (both in length and dry mass), photosynthesis and respiration rates, chlorophyll fluorescence variables, photosynthetic pigment composition (chlorophylls, carotenoids), DNA damage (presence of thymine dimers and other photoproducts), protein and glucid concentrations, mineral elements content, and the appearance of UV-absorbing compounds which could serve as a protective mechanism.
The results obtained are conflicting, since UV$\mathrm{B}$ radiation has been found to either stimulate, to depress, or to have no effect on bryophyte performance. Several studies have found a growth reduction in bryophytes when exposed to UV-B (Sonesson et al., 1996; Gehrke et al., 1996; Markham et al., 1998; Gehrke, 1998, 1999; Ballaré et al., 2001), but this effect seems to depend on the species considered, the experimental design and other additional factors such as water availability and $\mathrm{CO}_{2}$ concentration. Other harmful effects (chlorophyll degradation, reduction in photosynthesis rates and $\mathrm{F}_{\mathrm{v}} / \mathrm{F}_{\mathrm{m}}$ ) are even less clear, since contradictory results have been found. In addition, the increase in UV-absorbing compounds, which represents the most usual response of vascular plants to enhanced UV-B (Searles et al., 2001a), has only been manifested occasionally in bryophytes (Markham et al., 1990; Ihle \& Laasch, 1996; Newsham et al., 2002; Martínez-Abaigar et al., 2003a). Beneficial effects of UV-B radiation on bryophyte growth have also been reported (Johanson et al., 1995; Searles et al., 1999; Phoenix et al., 2001), which further complicates the global interpretation of the results. This controversy contrasts with intuitive thoughts that bryophytes would be strongly sensitive to UV-B radiation, because of their structural simplicity and the consequent lack of defenses commonly found in higher plants: thick cuticles, epicuticular waxes, epidermis (sometimes with several cell layers), hairs on leaf surfaces, etc. It must be taken into account that bryophyte "leaves" are mostly mono-stratified and lack air spaces, which dramatically reduces the radiation pathway and thus its attenuation. Thus, bryophytes (with the exception of thalloid forms, which have been understudied in relation to UV radiation), could only acquire chemical and metabolic defenses through, for instance, UV-absorbing compounds, antioxidant mechanisms, and repairing systems of DNA and photosynthetic machinery. However, the present knowledge on UV-absorbing compounds in bryophytes suggests that this mechanism does not occur in most bryophytes (Arróniz-Crespo et al., 2004), and the rest of 
the mechanisms have hardly been tested regarding UV-B radiation. Globally, the responses of bryophytes to UV-B radiation and their protect- ing systems are still poorly characterized, and thus further study is required both under controlled and field conditions.

Table 1. Original papers on the effects of UV radiation on bryophytes. Key for "Used Species": L, liverwort; M, moss. Key for "Ambient": T, terrestrial; P, peatlands; A, aquatic; R, rivers or streams; L, lakes. Key for "Type of Experiment": F, Field; G, greenhouse; L, laboratory; E, exclusion of UV-B radiation; S, supplement of UV-B radiation; N, samples exposed to natural levels of solar radiation; VSh, very short duration (less than 1 day); Sh, short duration (1-30 days); M, medium duration (longer than one month and shorter than 6 months); Lo, long duration (6 months - 1 year); VLo, very long duration (longer than 1 year); ?, undetermined duration; H, historical study (comparison of samples over a prolonged period). Key for "Variables used": A, alterations in DNA; Fl, chlorophyll fluorescence; FlS, fluorescence spectra; G, growth; H, hydric relations; M, morphology; Mt1, primary metabolites (glucids, proteins, lipids); Mt2, secondary metabolites, including UV-absorbing compounds; N, mineral nutrients; Ox, variables of oxidative stress (peroxide content, lipid peroxidation, ascorbate, superoxide dismutase, peroxidase, catalase); P, photosynthesis; Ph, phenology; PP, photosynthetic pigments; PS1 and PS2, activity of photosystems I and II, respectively; R, respiration; Rf, reflectance indices; Sc, sclerophylly; U, ultrastructure. Artículos originales relacionados con los efectos de la radiación UV sobre los briófitos. Clave para "Especies utilizadas": L, hepática; M, musgo. Clave para "Ambiente": T, terrestre; P, turberas; $A$, acuático; $R$, ríos o arroyos; L, lagos. Clave para "Tipo de experimento": $F$, campo; $G$, invernadero; L, laboratorio; E, exclusión de radiación $U V-B ; S$, suplemento de radiación UV-B; $N$, muestras expuestas a niveles naturales de radiación solar; VSh, duración muy corta (menos de 1 dia); Sh, duración corta (1-30 días); M, duración media (mayor de 1 mes y menor de 6 meses); Lo, duración larga (6 meses - 1 año); VLo, duración muy larga (mayor de 1 año); ?, duración indeterminada; H, estudio histórico (comparación de muestras a lo largo de un periodo prolongado). Clave para "Variables utilizadas": A, alteraciones en el ADN; Fl, fluorescencia de clorofila; FlS, espectros de fluorescencia; $G$, crecimiento; $H$, relaciones hídricas; $M$, morfología; Mt 1, metabolitos primarios (glúcidos, proteinas, lípidos); Mt2, metabolitos secundarios, incluyendo compuestos absorbentes de UV; $N$, nutrientes minerales; Ox, variables de estrés oxidativo (contenido de peróxido, peroxidación de lípidos, ascorbato, superóxido dismutasa, peroxidasa, catalasa); P, fotosíntesis; Ph, fenología; PP, pigmentos fotosintéticos; PS1 y PS2, actividad de los fotosistemas I y II, respectivamente; $R$, respiración; Rf, indices de reflectancia; Sc, esclerofilia; $U$, ultrastructura.

\begin{tabular}{lccc}
\hline Reference & Used species & Ambient $\begin{array}{c}\text { Type of Variables used } \\
\text { experiment }\end{array}$ \\
\hline
\end{tabular}

Arróniz-Crespo et al. (2004)

Ballaré et al. (2001)

Barsig et al. (1998)

Björn et al. (1998)

Conde-Álvarez et al. (2002)

Csintalan et al. (2001)

Gehrke (1998)

Gehrke (1999)

Gehrke et al. (1996)

Huiskes et al. (1999)

Huiskes et al. (2001)

Huttunen et al. (1998)
Chiloscyphus polyanthos (L), Jungermannia exsertifolia

subsp. cordifolia (L), Marsupella sphacelata (L), Scapania undulata (L), Brachythecium rivulare (M), Bryum alpinum (M), Bryum pseudotriquetrum (M), Fontinalis antipyretica (M), Palustriella commutata (M), Philonotis seriata (M), Polytrichum commune (M), Racomitrium aciculare $(\mathrm{M})$, Rhynchostegium riparioides (M), Sphagnum flexuosum $(\mathrm{M})$

Sphagnum magellanicum $(\mathrm{M})$

Polytrichum commune (M)

Aulacomnium turgidum (M), Dicranum elongatum (M), Hylocomium splendens (M), Polytrichum commune (M), P. hyperboreum (M), Sphagnum fuscum (M)

Riella helicophylla $(\mathrm{L})$

Dicranum scoparium (M), Leucobryum glaucum (M), Mnium hornum (M), Pellia epiphylla (L),

Plagiomnium undulatum (M), Plagiothecium undulatum (M), Polytrichum formosum (M),

Sphagnum capillifolium (M), Tortula ruralis (M)

Sphagnum fuscum (M)

Hylocomium splendens (M), Polytrichum commune (M)

Hylocomium splendens (M), Sphagnum fuscum (M)

Sanionia uncinata $(\mathrm{M})$

Sanionia uncinata $(\mathrm{M})$

Dicranum sp. (M), Hylocomium splendens (M),

Polytrichum commune (M)

A $(\mathrm{R}) \quad \mathrm{F}, \mathrm{N} \quad \mathrm{Mt} 2, \mathrm{Sc}$

$\begin{array}{ccc}\text { P } & \text { F, E, VLo } & \text { G, Mt2 } \\ \text { P } & \text { G, S, M } & \text { Mt1, Mt2, PP, U } \\ \text { T, P } & \text { F, S, M-VLo } & \text { G, H } \\ & & \\ \text { A (L) } & \text { L, E, VSh } & \text { Fl, Mt2, P, PP, R } \\ \text { T } & \text { L, S, Sh-M } & \text { F1, FlS, Mt2 }\end{array}$

$\begin{array}{ccc}\text { P } & \text { F, S, VLo } & \text { G, M, Mt2, P, PP, R } \\ \text { T, P } & \text { F, S, VLo } & \text { G, M, Mt2, PP } \\ \text { T, P } & \text { F, S, VLo } & \text { G, H, Mt2, PP } \\ \text { T } & - & - \\ \text { T } & \text { F, E, Sh } & \text { Fl } \\ \text { T, P } & \text { G, S, ? } & \text { M }\end{array}$


Table 1. Continued. Continuación.

\begin{tabular}{|c|c|c|c|c|}
\hline Reference & Used species & Ambient & $\begin{array}{c}\text { Type of } \\
\text { experiment }\end{array}$ & Variables used \\
\hline Huttunen et al. (2005a) & $\begin{array}{l}\text { Dicranum scoparium }(\mathrm{M}), \text { Funaria hygrometrica }(\mathrm{M}), \\
\text { Hylocomium splendens }(\mathrm{M}), \text { Pleurozium schreberi }(\mathrm{M}), \\
\text { Polytrichum commune }(\mathrm{M}), \text { Polytrichastrum alpinum }(\mathrm{M}) \text {, } \\
\text { Sphagnum angustifolium }(\mathrm{M}), \text { S. capillifolium }(\mathrm{M}), \\
\text { S. fuscum }(\mathrm{M}), \text { S. warnstorfi }(\mathrm{M})\end{array}$ & $\mathrm{T}, \mathrm{P}$ & $\mathrm{N}, \mathrm{H}$ & $\mathrm{M}, \mathrm{Mt} 2$ \\
\hline Huttunen et al. (2005b) & Hylocomium splendens (M), Pleurozium schreberi (M) & $\mathrm{T}$ & $\mathrm{N}, \mathrm{H}$ & $\mathrm{M}, \mathrm{Mt} 2$ \\
\hline Ihle (1997) & Conocephalum conicum $(\mathrm{L})$ & $\mathrm{T}$ & $\mathrm{L}, \mathrm{S}, \mathrm{VSh}$ & Mt1 \\
\hline Ihle \& Laasch (1996) & Conocephalum conicum (L) & $\mathrm{T}$ & L, S, VSh-Sh & $\mathrm{Fl}, \mathrm{Mt} 1, \mathrm{Mt} 2, \mathrm{P}$ \\
\hline Johanson et al. (1995) & Hylocomium splendens $(\mathrm{M})$ & $\mathrm{T}$ & $\mathrm{G}, \mathrm{S}, ?$ & $\mathrm{G}, \mathrm{Ph}$ \\
\hline Lewis Smith (1999) & $\begin{array}{l}\text { Bryum argenteum }(\mathrm{M}), \text { Bryum pseudotriquetrum }(\mathrm{M}), \\
\text { Ceratodon purpureus }(\mathrm{M})\end{array}$ & $\mathrm{T}$ & F, E, M & G \\
\hline $\begin{array}{l}\text { Lovelock \& Robinson } \\
\text { (2002) }\end{array}$ & $\begin{array}{l}\text { Bryum pseudotriquetrum }(\mathrm{M}), \text { Ceratodon purpureus }(\mathrm{M}) \text {, } \\
\text { Grimmia antarctici }(\mathrm{M})\end{array}$ & $\mathrm{T}$ & $\mathrm{F}, \mathrm{N}, ?$ & Mt2, PP, Rf \\
\hline Lud et al. (2002) & Sanionia uncinata $(\mathrm{M})$ & $\mathrm{T}$ & F, L, E, S, VSh-VLo & $\begin{array}{l}\text { A, G, Fl, M, } \\
\text { P, Mt2, PP }\end{array}$ \\
\hline Lud et al. (2003) & Sanionia uncinata $(\mathrm{M})$ & $\mathrm{T}$ & F, E, S, VSh-Sh & $\mathrm{A}, \mathrm{Fl}, \mathrm{Mt} 2, \mathrm{P}, \mathrm{PP}, \mathrm{R}$ \\
\hline Markham et al. (1990) & Bryum argenteum $(\mathrm{M})$ & $\mathrm{T}$ & $\mathrm{N}, \mathrm{H}$ & Mt2 \\
\hline Markham et al. (1998) & Marchantia polymorpha $(\mathrm{L})$ & $\mathrm{T}$ & $\mathrm{G}, \mathrm{S}, \mathrm{M}$ & $\mathrm{G}, \mathrm{M}, \mathrm{Mt} 2, \mathrm{Ph}$ \\
\hline $\begin{array}{l}\text { Martínez-Abaigar et al. } \\
\text { (2003a) }\end{array}$ & $\begin{array}{l}\text { Jungermannia exsertifolia subsp. cordifolia }(\mathrm{L}) \text {, } \\
\text { Fontinalis antipyretica }(\mathrm{M})\end{array}$ & $\mathrm{A}(\mathrm{R})$ & $\mathrm{L}, \mathrm{S}, \mathrm{M}$ & $\mathrm{Fl}, \mathrm{Mt} 2, \mathrm{P}, \mathrm{PP}, \mathrm{R}, \mathrm{Sc}$ \\
\hline $\begin{array}{l}\text { Martínez-Abaigar et al. } \\
(2003 \text { b) }\end{array}$ & $\begin{array}{l}\text { Jungermannia exsertifolia subsp. cordifolia (L), } \\
\text { Fontinalis antipyretica (M) }\end{array}$ & $A(R)$ & $\mathrm{L}, \mathrm{S}, \mathrm{M}$ & $\mathrm{G}, \mathrm{M}$ \\
\hline Montiel et al. (1999) & Sanionia uncinata $(\mathrm{M})$ & $\mathrm{T}$ & $\mathrm{F}, \mathrm{S}, ?$ & $\mathrm{Fl}$ \\
\hline Newsham (2003) & Andreaea regularis $(\mathrm{M})$ & $\mathrm{T}$ & $\mathrm{F}, \mathrm{N}, \mathrm{M}$ & Mt2, PP \\
\hline Newsham et al. (2002) & Sanionia uncinata (M), Cephaloziella varians (L) & $\mathrm{T}$ & F, N, Sh-M & F1, Mt2, PP \\
\hline Newsham et al. (2005) & Cephaloziella varians (L) & $\mathrm{T}$ & $\mathrm{F}, \mathrm{N}, \mathrm{E}, \mathrm{M}$ & $\mathrm{Mt} 2, \mathrm{PP}$ \\
\hline Niemi et al. (2002a) & $\begin{array}{l}\text { Sphagnum angustifolium (M), S. papillosum (M), } \\
\text { S. magellanicum }(\mathrm{M})\end{array}$ & $\mathrm{P}$ & F, S, M & $\mathrm{G}, \mathrm{Mt} 2, \mathrm{PP}$ \\
\hline Niemi et al. (2002b) & Sphagnum balticum (M), Sphagnum papillosum $(\mathrm{M})$ & $\mathrm{P}$ & $\mathrm{F}, \mathrm{S}, \mathrm{M}$ & G, Mt2, PP \\
\hline $\begin{array}{l}\text { Núñez-Olivera et al. } \\
\text { (2004) }\end{array}$ & $\begin{array}{l}\text { Jungermannia exsertifolia subsp. cordifolia }(\mathrm{L}) \\
\text { Fontinalis antipyretica }(\mathrm{M})\end{array}$ & $A(R)$ & $\mathrm{L}, \mathrm{S}, \mathrm{M}$ & $\begin{array}{l}\text { Fl, G, Mt1, Mt2, } \\
\text { P, PP, R, Sc }\end{array}$ \\
\hline $\begin{array}{l}\text { Núñez-Olivera et al. } \\
(2005)\end{array}$ & $\begin{array}{l}\text { Jungermannia exsertifolia subsp. cordifolia }(\mathrm{L}) \text {, } \\
\text { Fontinalis antipyretica }(\mathrm{M})\end{array}$ & $A(R)$ & L, S, Sh & $\begin{array}{l}\text { Fl, Mt1, Mt2, P, } \\
\text { PP, R, Sc }\end{array}$ \\
\hline Phoenix et al. (2001) & Hylocomium splendens $(\mathrm{M})$ & $\mathrm{T}$ & F, S, VLo & $\mathrm{G}, \mathrm{H}$ \\
\hline Post \& Vesk (1992) & Cephaloziella exiliflora (L) & $\mathrm{T}$ & F, N, Sh & M, Mt2, P, PP, U \\
\hline Prasad et al. (2004) & Riccia sp. (L) & $\mathrm{T}$ & $\mathrm{L}, \mathrm{S}, \mathrm{VSh}$ & Ox, PP, PS1, PS2 \\
\hline Rader \& Belish (1997a) & Fontinalis neomexicana (M) & $\mathrm{A}(\mathrm{R})$ & $\mathrm{F}, \mathrm{E}-\mathrm{S}, \mathrm{M}$ & $\mathrm{G}$ \\
\hline Robinson et al. (2005) & Grimmia antarctici $(\mathrm{M})$ & $\mathrm{T}$ & F, E, VLo & $\begin{array}{l}\text { Fl, H, M, Mt2, } \\
\quad \text { P, PP, Rf }\end{array}$ \\
\hline Robson et al. (2003) & Sphagnum magellanicum $(\mathrm{M})$ & $\mathrm{P}$ & F, E, VLo & $\mathrm{G}, \mathrm{M}$ \\
\hline Robson et al. (2004) & Sphagnum magellanicum (M) & $\mathrm{P}$ & F, E, VLo & $\mathrm{G}, \mathrm{M}$ \\
\hline Rozema et al. (2002) & Tortula ruralis $(\mathrm{M})$ & $\mathrm{T}$ & $\mathrm{F}, \mathrm{E}, ?$ & $\mathrm{G}, \mathrm{Mt} 2$ \\
\hline $\begin{array}{l}\text { Schipperges \& Gehrke } \\
\text { (1996) }\end{array}$ & Hylocomium splendens (M), Sphagnum fuscum (M) & $\mathrm{T}, \mathrm{P}$ & F-L, S, M- VLo & $\mathrm{G}, \mathrm{H}, \mathrm{P}$ \\
\hline Searles et al. (1999) & Sphagnum magellanicum $(\mathrm{M})$ & $\mathrm{P}$ & F, E, Lo & $\mathrm{G}, \mathrm{Mt} 2, \mathrm{PP}$ \\
\hline Searles et al. (2001b) & Sphagnum magellanicum (M) & $\mathrm{P}$ & F, E, VLo & $\mathrm{G}, \mathrm{M}, \mathrm{Mt} 2$ \\
\hline Searles et al. (2002) & Sphagnum magellanicum (M) & $\mathrm{P}$ & F, E, VLo & $\mathrm{G}, \mathrm{M}, \mathrm{Mt} 2, \mathrm{PP}$ \\
\hline Sonesson et al. (1996) & Hylocomium splendens $(\mathrm{M})$ & $\mathrm{T}$ & $\mathrm{L}, \mathrm{S}, \mathrm{M}$ & $\mathrm{G}, \mathrm{P}$ \\
\hline Sonesson et al. (2002) & Dicranum elongatum (M), Sphagnum fuscum (M) & $\mathrm{P}$ & F, S, VLo & $\mathrm{G}, \mathrm{H}$ \\
\hline $\begin{array}{l}\text { Taipale \& Huttunen } \\
\text { (2002) }\end{array}$ & Hylocomium splendens (M), Pleurozium schreberi (M) & $\mathrm{T}$ & F, S, M & Mt2 \\
\hline Takács et al. (1999) & $\begin{array}{l}\text { Dicranum scoparium }(\mathrm{M}), \text { Leucobryum glaucum }(\mathrm{M}) \text {, } \\
\text { Mnium hornum }(\mathrm{M}), \text { Pellia epiphylla }(\mathrm{L}) \text {, } \\
\text { Plagiothecium undulatum }(\mathrm{M}), \text { Polytrichum formosum }(\mathrm{M}) \text {, } \\
\text { Tortula ruralis }(\mathrm{M})\end{array}$ & $\mathrm{T}$ & G, S, Sh-M & $\mathrm{Fl}$ \\
\hline
\end{tabular}




\section{ULTRAVIOLET RADIATION AND AQUATIC BRYOPHYTES FROM MOUNTAIN STREAMS}

Before our studies, only two other ones had been conducted on the effects of UV radiation on truly aquatic bryophytes (see Table 1), despite the interest of how diverse organisms from different habitats respond to this environmental factor. In Conde-Álvarez et al. (2002), samples of the thalloid liverwort Riella helicophylla from a saline lake were cultivated throughout a natural daily light cycle under two radiation treatments: solar radiation (UV + photosynthetically active radiation or PAR) and solar radiation deprived of UV (PAR treatment). There were significant differences between the two treatments in the maximum quantum yield of photo-system II $\left(\mathrm{F}_{\mathrm{v}} / \mathrm{F}_{\mathrm{m}}\right)$, the effective quantum yield of photosynthetic energy conversion of PSII $\left(\Phi_{\text {PSII }}\right)$, the electron transport rate (ETR) and the initial slope of ETR vs. irradiance curve (all higher in PAR plants than in UV+PAR plants throughout the day), photosynthetic capacity (higher in PAR plants only at noon), chlorophyll $a$ (lower in UV+PAR only at 11.00), and phenolic compounds (higher in UV+PAR only at 13.30). No differences between treatments were found in dark respiration, photochemical quenching, and carotenoid concentration, and only slight ones in non-photochemical quenching (higher in $\mathrm{UV}+\mathrm{PAR}$ only in the morning). Thus, UV radiation (particularly UV-B) caused some damage to the photosynthetic apparatus. Recovery of inhibited photosynthesis took place in the afternoon, therefore solar UV radiation did not cause irreversible damage in the short term. Rader \& Belish (1997a) carried out a ten-week field experiment in which samples of the moss Fontinalis neomexicana were transplanted from a reference site to both a shaded and an open section of a mountain stream and were irradiated with enhanced levels of UV-B radiation. The transplants from the open site showed an important, although non-significant, reduction in dry biomass with respect to those growing under ambient conditions. However, the moss in this experiment failed to grow in any site and under any treatment condition, and there was a loss of material in all samples from the beginning to the conclusion of the experiment, which casts doubt on the significance of the results.

For several reasons, we circumscribe our research interest to the effects of UV-B radiation on aquatic bryophytes from mountain streams. Firstly, these ecosystems might be particularly exposed to the effects of UV-B radiation, since 1) the biologically active UV-B radiation increases between $5 \%$ and $20 \%$ per $1000 \mathrm{~m}$ altitudinal increase (Björn et al., 1998); 2) UV-B radiation can easily reach the organisms because they live at relatively low depths or even emersed, and UV-B radiation can penetrate into the oligotrophic waters typically occurring in mountain streams; and 3) the low temperatures which prevail during most of the year may limit the development of protection and repairing mechanisms against UV-B radiation. Secondly, bryophytes are the most abundant primary producers in mountain streams and are also important in nutrient cycles and food webs (Bowden et al., 1999; Núñez-Olivera et al., 2001). This domination suggests that they can withstand present levels of UV-B radiation, but the underlying physiological mechanisms are unknown and the structural protections against UV-B are lacking (as it was mentioned above for bryophytes as a group). Thirdly, bryophytes have an outstanding bio-indication ability in a number of pollution processes and environmental changes (see a recent review in Ah-Peng \& Rausch de Traubenberg, 2004), which could suggest their potential use as bio-indicators of changes in UVB levels. And finally, the scarcity of studies existing on this particular topic recommends increasing our knowledge on it, especially considering the present social interest on the causes and consequences of global climate change.

In our work, we have conducted both laboratory and field studies. In the laboratory, we have cultivated bryophytes under enhanced UV-B simulating a $20 \%$ ozone depletion, with the aim to characterize bryophyte responses to higher than present UV-B levels. The applied biologically effective UV-B $\left(\mathrm{UV}-\mathrm{B}_{\mathrm{BE}}\right)$ was $0.67 \mathrm{~W} \mathrm{~m}^{-2}$, equivalent to an exposure of $9.6 \mathrm{~kJ} \mathrm{~m}^{-2} \mathrm{~d}^{-1}$, 
which was calculated using the generalized plant damage action spectrum of Caldwell (1971). We established three general radiation regimes (PAR, PAR + UV-A, and PAR + UV-A + UV-B) to distinguish the effects of UV-A and UV-B radiations separately. Bryophyte responses were analyzed in terms of sclerophylly, the photosynthetic pigment composition, the rates of net photosynthesis and dark respiration, some variables of chlorophyll fluorescence, and the UVabsorbing compounds. In addition, we occasionally measured DNA damage (through the appearance of thymine dimers), protein concentration, length growth and morphological symptoms (both macro- and microscopic). The duration of the experiments was diverse, from 3 days to 4 months. We have concentrated our studies on two species, the moss Fontinalis antipyretica and the foliose liverwort Jungermannia exsertifolia subsp. cordifolia (hereafter $J$. cordifolia), which were always collected from streams between 1300 and $2000 \mathrm{~m}$ altitude.

The two bryophytes mentioned above responded differently to the enhancement in UV-B radiation under controlled conditions, while UVA radiation had a scarce biological effect (Martínez-Abaigar et al., 2003a), as it occurred in other experiments using bryophytes (Niemi et al., 2002a, 2002b). The samples of the moss which were irradiated with UV-B showed, with respect to the control, decreases in the chlorophyll and carotenoid concentration, the chlorophyll $a / b$ quotient, the chlorophylls/phaeopigments ratios, the net photosynthesis rates, the light saturation point, $\mathrm{F}_{\mathrm{v}} / \mathrm{F}_{\mathrm{m}}$ and ETR. They also showed increases in the sclerophylly index ("leaf" mass per area) and the dark respiration rates. The majority of these changes were indicative of plant stress and some of them had been previously found in bryophytes exposed to enhanced UV-B radiation. However, the UV-Birradiated samples of the liverwort only showed a decrease in $\mathrm{F}_{\mathrm{v}} / \mathrm{F}_{\mathrm{m}}$, which might be the most sensitive physiological variable to UV-B, together with a $20 \%$ increase in the concentration of UVabsorbing compounds. This defense mechanism, rarely described in bryophytes, would enable the liverwort to have a higher tolerance than the moss against UV-B radiation, at least under the specific experimental conditions used. Also, the increment of UV-absorbing compounds in the liverwort might be a useful ecophysiological tool in the bioindication of UV-B.

The different response of the two studied species to UV-B radiation was also evident in their morphological features (Martínez-Abaigar et al., 2003b). When exposed to enhanced UV-B, the moss showed brown colour, depressed growth, development of the central fibrilar body in the cells, chloroplast disappearance and presence of protoplasts progressively vesiculose, vacuolized and finally hyaline. These symptoms are little specific and have been described in several pleurocarpous mosses as a response to diverse processes of senescence and stress (both natural and anthropogenic). The uniquely specific response of the moss to enhanced UV-B was a colour change in the cell walls, from yellow to orange-brown. In contrast, the exposed samples of the liverwort looked healthy and their macroand microscopic appearances were quite similar to those of control samples.

In the laboratory, we also examined the influence of temperature $\left(2{ }^{\circ} \mathrm{C} v s .10^{\circ} \mathrm{C}\right)$ on the physiological and morphological responses of Fontinalis antipyretica and Jungermannia cordifolia to enhanced UV-B (Martínez-Abaigar et al., 2003b; Núñez-Olivera et al., 2004). The influence of temperature on the effects of UV-B radiation depended on the species: the higher the UV-B tolerance, the lower the influence of temperature. Also, different morphological and physiological variables showed varied responses to this influence. Particularly, the lower temperature used in our study enhanced the adverse effects of UV-B radiation on several important physiological variables $\left(\mathrm{F}_{\mathrm{v}} / \mathrm{F}_{\mathrm{m}}\right.$, growth and chlorophylls/phaeopigments ratios) in the UV-B-sensitive $F$. antipyretica, but not in the more UV-Btolerant $J$. cordifolia. Thus, the adverse effects of cold and UV-B radiation were apparently additive in the moss (probably because the development of protection mechanisms was limited by cold), whereas this additiveness was lacking in the liverwort. We conducted a Principal Components Analysis (PCA) for both species using 
the physiological data obtained in the experiments and confirmed their different response to the concomitant action of UV-B and cold.

Another environmental factor that can influence the response of different species to UV-B radiation is their previous field acclimation to sun or shade conditions (Núñez-Olivera et al., 2005). Shade samples of Fontinalis antipyretica were more sensitive to the UV-B treatment than sun samples, and $\mathrm{F}_{\mathrm{v}} / \mathrm{F}_{\mathrm{m}}$ was the physiological variable which better discriminated both types of samples, since it decreased $42 \%$ in the shade samples and only $27 \%$ in the sun samples at the end of the culture period. In Jungermannia cordifolia, controls and UV-B-treated samples were not significantly different in either the sun or the shade samples. PCAs for each species, ranking the physiological results along the culture period, strongly supported these points. In conclusion, the shade samples were more sensitive to UV-B than the sun samples, but only in the more UV-B-sensitive species.

We also determined that the sensitivity of bryophyte species to artificially enhanced UV-B could be tested without having to cultivate the samples for a long period. A continuous UV-B exposure of $78 \mathrm{~h}$ reproduced the differences in the responses of Fontinalis antipyretica and Jungermannia cordifolia, which had been previously found in longer experiments lasting 3682 days (Núñez-Olivera et al., 2005). For this short-term test, several culture conditions, which were known to accelerate the appearance of damage, were imposed: high ratio UVB/PAR, continuous UV-B exposure, and cold temperature. This type of fast test may therefore be used instead of long-duration tests to evaluate the UV-B tolerance of bryophytes.

The different nature of the protection mechanisms between mosses and liverworts, which had been previously pointed out for Fontinalis antipyretica and Jungermannia cordifolia under laboratory conditions, was tested in a field survey conducted for 14 aquatic bryophytes from mountain streams, 10 mosses and 4 liverworts (Arróniz-Crespo et al., 2004). The diverse species showed significantly different levels of methanol-extractable UV-absorbing compounds
(MEUVAC) and also different forms in their absorbance spectra in the UV band. The high levels of MEUVAC and the clearly hump-shaped spectra in the UV-B and UV-A wavelengths (280-400 nm), which were found in the liverworts, contrasted with the low levels and non hump-shaped spectra generally found in the mosses (except for Polytrichum commune). Thus, the accumulation of MEUVAC might represent a frequent and constitutive a protecting mechanism against UV-B radiation in liverworts, but not in mosses.

In another field experiment, we tested the effects of a natural altitudinal gradient of ultraviolet-B (UV-B) radiation, from 1140 to $1816 \mathrm{~m}$ altitude, on the physiology of 11 populations of Jungermannia cordifolia (Arróniz-Crespo, 2005). Several physiological variables showed significant linear relationships with altitude: global MEUVAC levels, the concentrations of two phenolic derivatives, $\mathrm{ETR}_{\max }$ and $\mathrm{NPQ}_{\max }$ increased with altitude, whereas photoinhibition percentage and respiration rates decreased. This was also confirmed by a PCA, since most of these variables represented significant loading factors ordinating populations by altitude. The characteristics shown by high-altitude populations may confer tolerance to high UV-B levels, and the specific response to UV-B of the two phenolic derivatives suggests that they could be used as indicators of the spatial changes in UV$B$ radiation. In addition, the concentrations of these two phenolic derivatives increased specifically under artificially enhanced UV-B radiation (unpublished results). An interesting question remains to be solved: could these compounds be used as indicators of temporal changes in UV-B, which could be related to ozone depletion?

\section{CONCLUSIONS AND PERSPECTIVES}

1. Our results demonstrate that the effects of UV-B radiation on aquatic bryophytes depend primarily on the species, and thus they do not constitute a single functional group in this respect. The different responses to UV-B are revealed not only by changes in colour or in 
key physiological variables, such as growth, chlorophyll concentration, photosynthesis rates or chlorophyll fluorescence parameters, but also by variables responsible for protecting mechanisms, such as the concentration of UV-absorbing compounds. In particular, the constitutive presence and/or inducible enhancement of UV-absorbing compounds depend strongly on the species and, outstandingly, on the type of bryophyte (moss or liverwort) considered.

2. It is recommendable to evaluate UV-B sensitivity in sufficiently prolonged experiments, however short-term $(72 \mathrm{~h})$ tests may render comparable results.

3. The responses of aquatic bryophytes to UV-B radiation depend not only on specific genetic factors, but also on environmental factors (such as temperature) and the origin of the samples (sun or shade conditions, low or high altitude). The effects of these factors depend on the species: in the UV-B sensitive ones, both cold and previous shade acclimation may exacerbate the harmful effects of enhanced UV-B.

4. Among the variables measured under laboratory conditions, the maximum quantum yield of photo-system II $\left(\mathrm{F}_{\mathrm{v}} / \mathrm{F}_{\mathrm{m}}\right)$ and the level of UV-absorbing compounds seem to be the most responsive ones to enhanced UV-B. However, no variable responds in the same manner in every species, which still limits our global comprehension on the effects of UV-B on bryophytes. The positive thing here is that a "UV-B syndrome" may be identified by the treatment of physiological data of control and UV-B-exposed samples through multivariant analyses (such as PCA), since both types of samples usually appear clearly separated in the generated plots.

5 . The noteworthy variability of the results reported in the literature on the effects of UV radiation on bryophytes may be due to the above-mentioned diversity of species, environmental factors, variables and experimental conditions used in the different studies. Thus, it is necessary to take into account the methodological approaches to appropriately interpret the results obtained.
6. The use of aquatic bryophytes as bio-indicators of changes in UV-B radiation requires an adequate selection of both variables and species. Promising variables regarding this point are $F_{v} / F_{m}$, because of its sensitivity to UV-B, and the concentration of UV-absorbing compounds, due to its remarkable specificity of response. The analysis of individual UVabsorbing compounds may have a stronger ecological and physiological relevance than the usual global analysis of these compounds, since each one may respond in a different manner to UV-B. Thus, a previous identification of the compounds occurring in the different species is clearly needed. A third variable potentially useful for bio-indication purposes could be the evaluation of DNA damage caused specifically by UV-B radiation. Regarding the species selection, our results point at Jungermannia cordifolia because of its good responsiveness to UV-B, availability of healthy biomass throughout the year (if populations are selected properly), and wide distribution range over mountain streams of the northern hemisphere.

7. Two phenolic derivatives from Jungermannia cordifolia which absorb UV radiation have shown their ability to increase in response to a field spatial gradient of UV-B. The future combination of laboratory and field works studying the behaviour of these compounds under different UV treatments, and particularly the field assessment of their seasonal and inter-annual variations in response to temporal changes in ambient UV-B, could allow for the development of a protocol of bio-indication of the potential increase in UV$\mathrm{B}$ radiation due to ozone depletion.

\section{ACKNOWLEDGEMENTS}

We are grateful to the Ministerio de Educación y Ciencia of Spain and the Fondo Europeo de Desarrollo Regional (FEDER), and to the Government of La Rioja (Consejería de Educación, Cultura, Juventud y Deportes), for their financial support through the Projects 
REN2002-03438/CLI, CGL2005-02663/BOS and ACPI 2003/06. Saúl Otero and María Arróniz-Crespo benefited from grants of the Spanish Ministerio de Educación y Ciencia.

\section{REFERENCES}

AH-PENG, C. \& C. RAUSCH DE TRAUBENBERG. 2004. Bryophytes aquatiques bioaccumulateurs de polluants et indicateurs écophysiologiques de stress: synthèse bibliographique. Cryptog. Bryol., 25: 205-248.

ALLEN, D. J., S. NOGUÉS \& N. R. BAKER. 1998. Ozone depletion and increased UV-B radiation: is there a real threat to photosynthesis? J. Exp. Bot., 49: $1775-1788$.

ARRÓNIZ-CRESPO, M., E. NÚÑEZ-OLIVERA, J. MARTÍNEZ-ABAIGAR \& R. TOMÁS. 2004. A survey of the distribution of UV-absorbing compounds in aquatic bryophytes from a mountain stream. Bryologist, 107: 202-208.

ARRÓNIZ-CRESPO, M. 2005. Efectos de la radiación ultravioleta-B sobre briófitos acuáticos de ríos de montaña. Tesis Doctoral, Universidad de La Rioja. 226 pp.

BALLARÉ, C. L., M. C. ROUSSEAUX, P. S. SEARLES, J. G. ZALLER, C. V. GIORDANO, T. M. ROBSON, M. M. CALDWELL, O. E. SALA \& A. L. SCOPEL. 2001. Impacts of solar ultraviolet-B radiation on terrestrial ecosystems of Tierra del Fuego (Southern Argentina). An overview of recent progress. J. Photochem. Photobiol. B: Biol., 62: 67-77.

BARSIG, M., K. SCHNEIDER \& C. GEHRKE. 1998. Effects of UV-B radiation on fine structure, carbohydrates, and pigments in Polytrichum commune. Bryologist, 101: 357-365.

BJÖRN, L. O., T. V. CALLAGHAN, C. GEHRKE, U. JOHANSON, M. SONESSON \& D. GWYNNJONES. 1998. The problem of ozone depletion in northern Europe. Ambio, 27: 275-279.

BJÖRN, L. O. 1999. Ultraviolet-B radiation, the ozone layer and ozone depletion. In: Stratospheric ozone depletion: the effects of enhanced $U V-B$ radiation on terrestrial ecosystems. J. Rozema (ed.): 21-37. Backhuys Publishers, Leiden.

BOWDEN, W. B., D. ARSCOTT, D. PAPPATHANASI, J. FINLAY, J. M. GLIME, J. LACROIX, C. L. LIAO, A. HERSHEY, T. LAMPELLA, B. PETERSON, W. WOLLHEIM, K. SLAVIK, B. SHELLEY, M. B. CHESTERTON, J. A. LACHANCE,
R. M. LEBLANC, A. STEINMAN \& A. SUREN. 1999. Roles of bryophytes in stream ecosystems. J. N. Am. Benthol. Soc., 18: 151-184.

CALDWELL, M. M. 1971. Solar UV irradiation and the growth and development of higher plants. In: Photophysiology: current topics in photobiology and photochemistry, Vol. 6. A.C. Giese (ed.): 131177. Academic Press, New York.

CALDWELL, M. M., L. O. BJÖRN, J. F. BORNMAN, S. D. FLINT, G. KULANDAIVELU, A. H. TERAMURA \& M. TEVINI. 1998. Effects of increased solar ultraviolet radiation on terrestrial ecosystems. J. Photochem. Photobiol. B: Biol., 46: 40-52.

CONDE-ÁLVAREZ，R. M., E. PÉREZ-RODRÍGUEZ, M. ALTAMIRANO, J. M. NIETO, R. ABDALA, F. L. FIGUEROA \& A. FLORESMOYA. 2002. Photosynthetic performance and pigment content in the aquatic liverwort Riella helicophylla under natural solar irradiance and solar irradiance without ultraviolet light. Aquat. Bot., 73: 47-61.

CSINTALAN, Z., Z. TUBA, Z. TAKÁCS \& E. LAITAT. 2001. Responses of nine bryophyte and one lichen species from different microhabitats to elevated UV-B radiation. Photosynthetica, 39: 317-320.

DAY, T. A. \& P. J. NEALE. 2002. Effects of UV-B radiation on terrestrial and aquatic primary producers. Ann. Rev. Ecol. Syst., 33: 371-396.

FIGUEROA, F. L. \& I. GÓMEZ. 2001. Photosynthetic acclimation to solar UV radiation of marine red algae from the warm-temperate coast of south Spain: a review. J. Appl. Phycol., 13: 235-248.

FISCUS, E. L. \& F. L. BOOKER. 1995. Is increased UV-B a threat to crop photosynthesis and productivity? Photosynth. Res., 43: 81-92.

GEHRKE, C., U. JOHANSON, D. GWYNNJONES, L. O. BJÖRN, T. V. CALLAGHAN \& J. A. LEE. 1996. Effects of enhanced ultraviolet-B radiation on terrestrial subarctic ecosystems and implications for interactions with increased atmospheric $\mathrm{CO}_{2}$. Ecol. Bull., 45: 192-203.

GEHRKE, C. 1998. Effects of enhanced UV-B radiation on production related properties of a Sphagnum fuscum dominated subarctic bog. Funct. Ecol., 12: 940-947.

GEHRKE, C. 1999. Impacts of enhanced ultraviolet$B$ radiation on mosses in a subarctic heath ecosystem. Ecology, 80: 1844-1851.

HÄDER, D. P., H. D. KUMAR, R. C. SMITH \& R. C. WORREST. 2003. Aquatic ecosystems: effects 
of solar ultraviolet radiation and interactions with other climatic change factors. Photochem. Photobiol. Sci., 2: 39-50.

HELBLING, E. W. \& H. E. ZAGARESE (eds.). 2003. UV effects in aquatic organisms and ecosystems. Oxford: Royal Society of Chemistry. 575 pp.

HUISKES, A. H. L., D. LUD, T. C. W. MOERDIJKPOORTVLIET \& J. ROZEMA. 1999. Impact of UV-B radiation on Antarctic terrestrial vegetation. In: Stratospheric ozone depletion: the effects of enhanced UV-B radiation on terrestrial ecosystems. J. Rozema (ed.): 313-337. Backhuys Publishers, Leiden.

HUISKES, A. H. L., D. LUD \& T. C. W. MOERDIJK-POORTVLIET. 2001. Field research on the effects of UV-B filters on terrestrial Antarctic vegetation. Plant Ecol., 154: 77-86.

HUOVINEN, P. S. \& C. R. GOLDMAN. 2000. Inhibition of phytoplankton production by UV-B radiation in clear subalpine Lake Tahoe, California-Nevada. Verh. Internat. Verein. Limnol., 27: 157-160.

HUTTUNEN, S., H. KINNUNEN \& K. LAAKSO. 1998. Impact of increased UV-B on plant ecosystems. Chemosphere, 36: 829-833.

HUTTUNEN, S., N. M. LAPPALAINEN \& J. TURUNEN. 2005a. UV-absorbing compounds in subarctic herbarium bryophytes. Environ. Pollut., 133: 303-314.

HUTTUNEN, S., T. TAIPALE, N. M. LAPPALAINEN, E. KUBIN, K. LAKKALA \& J. KAUROLA. 2005b. Environmental specimen bank samples of Pleurozium schreberi and Hylocomium splendens as indicators of the radiation environment at the surface. Environ. Pollut., 133: 315326.

IHLE, C. \& H. LAASCH. 1996. Inhibition of photosystem II by UV-B radiation and the conditions for recovery in the liverwort Conocephalum conicum Dum. Bot. Acta, 109: 199-205.

IHLE, C. 1997. Degradation and release from the thylakoid membrane of Photosystem II subunits after UV-B irradiation of the liverwort Conocephalum conicum. Photosynth. Res., 54: 73-78.

JANSEN, M. A. K., V. GABA \& B. M. GREENBERG. 1998. Higher plants and UV-B radiation: balancing damage, repair and acclimation. Trends Plant Sci., 3: 131-135.

JOHANSON, U., C. GEHRKE, L. O. BJÖRN, T. V. CALLAGHAN \& M. SONESSON. 1995. The effects of enhanced UV-B radiation on a subarctic heath ecosystem. Ambio, 24: 106-111.

KELLY, D. J., M. L. BOTHWELL \& D. W. SCHINDLER. 2003. Effects of solar ultraviolet radiation on stream benthic communities: an intersite comparison. Ecology, 84: 2724-2740.

LAURION, I., M. VENTURA, J. CATALÁN, R. PSENNER \& R. SOMMARUGA. 2000. Attenuation of ultraviolet radiation in mountain lakes: Factors controlling the among- and within-lake variability. Limnol. Oceanogr., 45: 1274-1288.

LEWIS SMITH, R. I. 1999. Biological and environmental characteristics of three cosmopolitan mosses dominant in continental Antarctica. J. Veg. Sci., 10: 231-242.

LOVELOCK, C. E. \& S. A. ROBINSON. 2002. Surface reflectance properties of Antarctic moss and their relationship to plant species, pigment composition and photosynthetic function. Plant Cell Environ., 25: 1239-1250.

LUD, D., T. C. W. MOERDIJK, W. H. VAN DE POLL, A. G. J. BUMA \& A. H. L. HUISKES. 2002. DNA damage and photosynthesis in Antarctic and Arctic Sanionia uncinata (Hedw.) Loeske under ambient and enhanced levels of UVB radiation. Plant Cell Environ., 25: 1579-1589.

LUD, D., M. SCHLENSOG, B. SCHROETER \& A. H. L. HUISKES. 2003. The influence of UV-B radiation on light-dependent photosynthetic performance in Sanionia uncinata (Hedw.) Loeske in Antarctica. Polar Biol., 26: 225-232.

MARKHAM, K. R., A. FRANKE, D. R. GIVEN \& P. BROWNSEY. 1990. Historical Antarctic ozone level trends from herbarium specimen flavonoids. Bull. Liaison Groupe Polyphenols, 15: 230-235.

MARKHAM, K. R., K. G. RYAN, S. J. BLOOR \& K. A. MITCHELL. 1998. An increase in the luteolin:apigenin ratio in Marchantia polymorpha on UV-B enhancement. Phytochemistry, 48: 791-794.

MARTÍNEZ-ABAIGAR, J., E. NÚÑEZ-OLIVERA, N. BEAUCOURT, M. A. GARCÍA-ÁLVARO, R. TOMÁS \& M. ARRÓNIZ. 2003a. Different physiological responses of two aquatic bryophytes to enhanced ultraviolet-B radiation. J. Bryol., 25: 17-30.

MARTÍNEZ-ABAIGAR, J., E. NÚÑEZ-OLIVERA, R. TOMÁS, N. BEAUCOURT, M. A. GARCÍAÁlVARO \& M. ARRÓNIZ. 2003b. Daños macroscópicos y microscópicos causados por un aumento de la radiación ultravioleta-B en dos briófitos acuáticos del Parque Natural de Sierra Cebollera (La Rioja). Zubía, 21: 29-49. 
MCKENZIE, R. L., L. O. BJÖRN, A. BAIS \& M. ILYASD. 2003. Changes in biologically active ultraviolet radiation reaching the Earth's surface. Photochem. Photobiol. Sci., 2: 5-15.

MONTIEL, P., A. SMITH \& D. KEILLER. 1999. Photosynthetic responses of selected Antarctic plants to solar radiation in the southern maritime Antarctic. Polar Res., 18: 229-235.

NEWSHAM, K. K., D. A. HODGSON, A. W. A. MURRAY, H. J. PEAT \& R. I. LEWIS SMITH. 2002. Response of two Antarctic bryophytes to stratospheric ozone depletion. Global Change Biol., 8: 972-983.

NEWSHAM, K. K. 2003. UV-B radiation arising from stratospheric ozone depletion influences the pigmentation of the Antarctic moss Andreaea regularis. Oecologia, 135: 327-331.

NEWSHAM, K. K., P. GEISSLER, M. NICOLSON, H. J. PEAT \& R. I. LEWIS-SMITH. 2005. Sequential reduction of UV-B radiation in the field alters the pigmentation of an Antarctic leafy liverwort. Environ. Exp. Bot., 54: 22-32.

NIEMI, R., P. J. MARTIKAINEN, J. SILVOLA, A. WULFF, S. TURTOLA \& T. HOLOPAINEN. 2002a. Elevated UV-B radiation alters fluxes of methane and carbon dioxide in peatland microcosms. Global Change Biol., 8: 361-371.

NIEMI, R., P. J. MARTIKAINEN, J. SILVOLA, E. SONNINEN, A. WULFF \& T. HOLOPAINEN. 2002b. Responses of two Sphagnum moss species and Eriophorum vaginatum to enhanced UV-B in a summer of low UV intensity. New Phytol., 156: 509-515.

NÚÑEZ-OLIVERA, E., A. GARCÍA-ÁLVARO, N. BEAUCOURT \& J. MARTÍNEZ-ABAIGAR. 2001. Changes in element concentrations in aquatic bryophytes over an annual cycle. Arch. Hydrobiol., 152: 253-277.

NÚÑ̃EZ-OLIVERA, E., J. MARTÍNEZ-ABAIGAR, R. TOMÁS, N. BEAUCOURT \& M. ARRÓNIZCRESPO. 2004. Influence of temperature on the effects of artificially enhanced UV-B radiation on aquatic bryophytes under laboratory conditions. Photosynthetica, 42: 201-212.

NÚÑEZ-OLIVERA, E., M. ARRÓNIZ-CRESPO, J. MARTÍNEZ-ABAIGAR, R. TOMÁS \& N. BEAUCOURT. 2005. Assessing the UV-B tolerance of sun and shade samples of two aquatic bryophytes using short-term tests. Bryologist, 108: 435-448.

PHOENIX, G. K., D. GWYNN-JONES, T. V. CALLAGHAN, D. SLEEP \& J. A. LEE. 2001.
Effects of global change on a sub-Arctic heath: effects of enhanced UV-B radiation and increased summer precipitation. J. Ecol., 89: 256-267.

POST, A. \& M. VESK. 1992. Photosynthesis, pigments, and chloroplast ultrastructure of an Antarctic liverwort from sun-exposed and shaded sites. Can. J. Bot., 70: 2259-2264.

PRASAD, S. M., R. DWIVEDI, M. ZEESHAN \& R. SINGH. 2004. UV-B and cadmium induced changes in pigments, photosynthetic electron transport activity, antioxidant levels and antioxidative enzyme activities of Riccia sp. Acta Physiol. Plant., 26: 423-430.

RADER, R. B. \& T. A. BELISH. 1997a. Short-term effects of ambient and enhanced UV-B on moss (Fontinalis neomexicana) in a mountain stream. $J$. Freshw. Ecol., 12: 395-403.

RADER, R. B. \& T. A. BELISH. 1997b. Effects of ambient and enhanced UV-B radiation on periphyton in a mountain stream. J. Freshw. Ecol., 12: 615-628.

RAE, R., D. HANELT \& I. HAWES. 2001. Sensitivity of freshwater macrophytes to UV radiation: relationship to depth zonation in an oligotrophic New Zealand lake. Mar. Freshw. Res., 52: 1023-1032.

ROBINSON, S. A., J. D. TURNBULL \& C. E. LOVELOCK. 2005. Impact of changes in natural ultraviolet radiation on pigment composition, physiological and morphological characteristics of the Antarctic moss, Grimmia antarctici. Global Change Biol., 11: 476-489.

ROBSON, T. M., V. A. PANCOTTO, S. D. FLINT, C. L. BALLARÉ, O. E. SALA, A. L. SCOPEL \& M. M. CALDWELL. 2003. Six years of solar UV-B manipulations affect growth of Sphagnum and vascular plants in a Tierra del Fuego peatland. New Phytol., 160: 379-389.

ROBSON, T. M., V. A. PANCOTTO, C. L. BALLARÉ, O. E. SALA, A. L. SCOPEL \& M. M. CALDWELL. 2004. Reduction of solar UV-B mediates changes in the Sphagnum capitulum microenvironment and the peatland microfungal community. Oecologia, 140: 480-490.

ROUSSEAUX, M. C., S. D. FLINT, P. S. SEARLES \& M. M. CALDWELL. 2004. Plant responses to current solar ultraviolet-B radiation and to supplemented solar ultraviolet-B radiation simulating ozone depletion: An experimental comparison. Photochem. Photobiol., 80: 224-230.

ROZEMA, J., L. O. BJÖRN, J. F. BORNMAN, A. GABERSCIK, D. P. HÄDER, T. TROST, M. 
GERM, M. KLISCH, A. GRÖNIGER, R. P. SINHA, M. LEBERT, Y. Y. HE, R. BUFFONIHALL, N. V. J. DE BAKKER, J. VAN DE STAAIJ \& B. B. MEIJKAMP. 2002. The role of UV-B radiation in aquatic and terrestrial ecosystems - an experimental and functional analysis of the evolution of UV-absorbing compounds. J. Photochem. Photobiol. B: Biol., 66: 2-12.

SCHIPPERGES, B. \& C. GEHRKE. 1996. Photosynthetic characteristics of subarctic mosses and lichens. Ecol. Bull., 45: 121-126.

SEARLES, P. S., S. D. FLINT, S. B. DÍAZ, M. C. ROUSSEAUX, C. L. BALLARÉ \& M. M. CALDWELL. 1999. Solar ultraviolet-B radiation influence on Sphagnum bog and Carex fen ecosystems: first field season findings in Tierra del Fuego, Argentina. Global Change Biol., 5: 225234.

SEARLES, P. S., S. D. FLINT \& M. M. CALDWELL. 2001a. A meta-analysis of plant field studies simulating stratospheric ozone depletion. Oecologia, 127: 1-10.

SEARLES, P. S., B. R. KROPP, S. D. FLINT \& M. M. CALDWELL. 2001b. Influence of solar UV-B radiation on peatland microbial communities of southern Argentina. New Phytol., 152: 213-221.

SEARLES, P. S., S. D. FLINT, S. B. DÍAZ, M. C. ROUSSEAUX, C. L. BALLARÉ \& M. M. CALDWELL. 2002. Plant response to solar ultraviolet-B radiation in a southern South American Sphagnum peatland. J. Ecol., 90: 704-713.
SONESSON, M., T. V. CALLAGHAN \& B. A. CARLSSON. 1996. Effects of enhanced ultraviolet radiation and carbon dioxide concentration on the moss Hylocomium splendens. Global Change Biol., 2: 67-73.

SONESSON, M., B. A. CARLSSON, T. V. CALLAGHAN, S. HALLING, L. O. BJÖRN, M. BERTGREN \& U. JOHANSON. 2002. Growth of two peat-forming mosses in subarctic mires: species interactions and effects of simulated climate change. Oikos, 99: 151-160.

TAIPALE, T. \& S. HUTTUNEN. 2002. Moss flavonoids and their ultrastructural localization under enhanced UV-B radiation. Polar Record, 38: 211-218.

TAKÁCS, Z., Z. CSINTALAN, L. SASS, E. LAITAT, I. VASS \& Z. TUBA. 1999. UV-B tolerance of bryophyte species with different degrees of desiccation tolerance. J. Photochem. Photobiol. B: Biol., 48: 210-215.

VANICEK, K., T. FREI, Z. LITYNSKA \& A. SCHMALWIESER. 1999. UV-Index for the public. A guide for publication and interpretation of solar UV Index forecasts for the public prepared by the Working Group 4 of the COST-713 Action "UV-B Forecasting". Brussels: European Union. $40 \mathrm{pp}$.

VILLAFAÑE, V.E., M. ANDRADE, V. LAIRANA, F. ZARATTI \& E.W. HELBLING. 1999. Inhibition of phytoplankton photosynthesis by solar ultraviolet radiation: studies in Lake Titicaca, Bolivia. Freshwat. Biol., 42: 215-224. 